\title{
Fight for the education of the Aymara communities of Puno (Peru)
}

\author{
Vicente Alanoca Arocutipa ${ }^{1}$, Cesario Ticona Alanoca ${ }^{2}$
}

\author{
${ }^{1}$ Escuela Profesional de Antropología, Facultad de Ciencias Sociales, Nacional del Altiplano, Puno, PERÚ. \\ Email: valanoca2002@yahoo.es \\ ${ }^{2}$ Escuela Profesional de Antropología, Facultad de Ciencias Sociales, Nacional del Altiplano, Puno, PERÚ. \\ Email: cta_1955@hotmail.com
}

\begin{abstract}
The article refers to the historical process of struggle for education undertaken by the Aymara communities in the Puno region (Peru). The objective is to visualize the main facts and moments of vindication and identifies the challenges and hopes, which still demand at present. In the results, the struggle to read and write has been identified in the first place; second, the conquest of the school by the communities; and in the third part the impertinence of education or the decontextualization of the school is visualized. The methodology used was ethnography, exploring events in the struggle for the education of the communities, providing descriptive data about the media, contexts and the participants involved in the historical process. It has identified actors such as the State, the community and the school, and the main aspects, social, political, economic and environmental, linked to the daily activities of agriculture and livestock. Capitalism has understood education as a commodity. The challenges and hopes are the demand and the permanent struggle for an education of relevance and contextualized, which could be assumed by the State with equity and justice in educational policy decisions.
\end{abstract}

Keywords-Aymara community, vindication, education, racism, exclusion.

\section{INTRODUCTION}

At present, many countries in the world face economic, environmental and insecurity problems, which are somehow recreating the solution from the various state apparatuses, although some are irreversible, but there is a more serious situation that has taken root and it has been institutionalized at different levels of government, such as corruption. From the actors and political decision-makers of education, there may be efforts to defend some people who had the responsibility to govern the countries from the curricular contents. In this context, the official history via school was an accomplice of the legitimation of forgetfulness (Alanoca, 2012; 2013; 2016), not only of the wisdom of the people, but also of the most cruel and corrupt facts that today involves the political class in the
Peruvian case, where the Quechua, Aymara and Amazonian populations continue to be systematically excluded and fight for equality and justice. On the other hand, interethnic relations are, in turn, associated with social inequalities and power relations.

In this context, the problems addressed by great national and international figures, leaders and scholars are still valid, such as: Mariátegui (1928), Burga, Hidalgo, and Trapnell, (2012), Frisancho (1946) Albo (1988), Matos (1984) ), among others. Those who diagnosed the problems of exclusion and systematic discrimination from the State. Such problems have not been solved with the school, rather they have recreated the forms and strategies of submission that capitalism has been imposing and printing from the different spaces and levels of education. The struggle for education in the indigenous peoples of countries such as Peru, Bolivia, among others, has historical data (Valcarcel, 1973). In our case, the struggle for education for the Aymara people can be approached from different perspectives, knowing that, from the State, that is, national education, therefore, does not have a national spirit: it has a colonial spirit and colonizer (Mariategui, 2002). In the same way there are different currents and theories of learning that come to be the support of legitimation, such as classical, behavioral, sociocultural, humanistic and cognitive of education (Araujo, 2013). It is important to know that, historically, many towns and current provincial capitals have their origin in the reductions of Indians ordered by Viceroy Toledo in the late sixteenth century. But, these towns also became the head of the positions of authority and services of the Spaniards. In fact, the Aymara peasants have tended to consider the villagers as 'misti q'ara', they have felt linked to the Spanish and Creole and have tried to distinguish themselves clearly from "the Indian". In this social sense there is a notable barrier between Aymara and village neighbors (Albó, 1992).

The present work is structured under the objective of visualizing the school struggle promoted by the community leaders of the Aymara communities (PunoPeru), that there is scarce literature about it, more there 
are living testimonies of managers and leaders of the Aymara communities today fragmented in the case of Puno in six Aymara provinces. In that sense it is approached in three moments, first of all the fight for the school was for the literacy of the Spanish, assuming the language as an instrument of liberation and justice, which could solve the school. The second part refers to the conquest of the school for the communities, but today disconnected and decontextualized from the community. And the third part is visualized from the testimonies and interviews the main remains and hopes that are still felt in the Aymara communities, but this problem was not taken seriously by the different actors and managers of the Peruvian educational system.

It has been tracked since the creation and management of the schools in the different Aymara communities, from some interviews to some community leaders from where it was possible to make visible and verify, not only schools, but schools and some institutes, including affiliates of universities. In the same way we have constituted each province and some communities, we obtained and verify unpublished histories of struggle for emancipation via school, for that reason, for the inhabitants the school, has a connotation of struggle for education. On the other hand, some experts were consulted, at the same time different bibliographical sources and documents have been revised. Which has allowed us to confirm some ideas and affirmations about the struggle for education for the Aymara communities of Puno.

\section{THE AYMARAS AND THE HISTORICAL PROCESS OF STRUGGLE TO READ AND WRITE}

The Aymaras with the founding of the states of Peru, Bolivia, Chile and Argentina were fragmented and mutilated in their process of cultural, social, political and economic development. Historically they have always been objects of discrimination and exclusion. One of the problems assumed and understood by the Aymara communities was the importance of access and use of the Castilian language. Consequently, the marginalization was because they were monolingual; that is, they only spoke Aymara. Not only were they stigmatized as illiterate, but ignorant, they suffered the most inhuman treatment form constantly. They had no right to education and were not qualified to hold public office, one of the essential requirements was to be able to read and write Spanish. Therefore, access to education for indigenous peoples became a demand that was not understood by the system (Mallea, 2016). The events reveal the clash of interests, prejudices and values, put to the test the effectiveness of ideas to develop proposals that would allow not only stability, but also new institutional arrangements within the limits, little less than unpublished, (Weingberg, 1984), because it is still pending to make visible that struggle of the peoples for education for emancipation.

There are several unpublished experiences on the education struggle in the Aymara area, which for reasons of racism have not been studied, for example the role assumed by the teacher Filomena Iglesias in Pomata, who had to work with women, knowing that a human being without language it is not such a human being. And a person with a poor language, without relief of poor development, is only a person half (Malmberg, 1966). The villagers in the communities had assimilated from their experience, not knowing the Castilian as: "jani aruni" 'without voice', for it was evident the fight for the school to get out of the abuses by the landowners and the 'mistis' ' For this, they recreated different strategies of struggle and management for the right to school.

In Puno, the Orkapata group had been formed, led by Arturo Peralta known as Gamaliel Churata. It was a school, creator of thoughts about all indigenous people, where different personalities of the progressive intellectuality of Puneña traveled, that today is needed in the country. From Puno, he identified with the indigenista movement of Cusco and Bolivia and from the three points he illuminated the whole America, infusing a new attitude to the generations, an attitude with a vision of ours, what we call deep Peru (Portugal, 2013). From this Orkapata group other groups will be constituted in the provincial capitals from where they will dedicate themselves to publish some publications that today are treasures of the history of Puno, that have not been understood by the system in their times, because in it radiography the harsh reality that the residents of the Aymara communities went through. At present, some intellectuals from Europe, Asia and other continents have put their eyes and hands in unraveling the thought of Gamaliel Churata.

Between the years 1965 and 1985, a diversity of schools will be created in the Aymara communities of Puno, assimilated from the settlers as a space of struggle and emancipation for justice and equality, which could solve the problem of linguistic discrimination. In fact it had an impact on the struggle for education, but deep down it became an apparatus and element par excellence of "cognitive epistemicide" (Santos de Sousa, 2017), because first it annihilated the native language, in this case the language Aymara, obviously with her wisdom. Although some teachers put all their effort for an education that values local wisdom, but the system choked them. In the XXI century we continue facing the same problems, we have not left that phrase, "the School instead of preparing the future citizen, is isolated and 
helpless" (Encinas, 2007). We are witnessing and living in Puno and in Peru those consequences in education, where children have been formatted decontextualized realities to the problems of everyday life.

From an observation of the educational reality of Puno and especially from the Aymara context, the school was and still is disconnected, in an unequal and different context (García, 2004). From the other shore it is necessary to open fissures from the meaning of Bilingual Intercultural Education in the Aymara claim, as it was seen as an alternative, which Cerrón-Palomino announced in a local communication medium when referring to Bilingual Intercultural Education (EIB), like: "a farce mounted by the government under pressure from some international organizations". "(The governments) have always manipulated these concepts and tried to sell us a bilingual cultural policy and, in the long run, what we have seen is simply a contentment with statistical results, with reports made in a general way and an oversight of the reality of each field of work "(Cerrón-Palomino, 2016). This situation was a hard question to those who had to see, and are still committed to the famous EIB. They could not miss the reactions of the detractors of the Cerrón-Palomino scholar, the important thing is that it puts in question and debate the subject. Because it is known, several institutions of initial and primary level in the Puno region develop IBE, but have not yet found strategies for an education with a sense of relevance.

Importantly, the history of indigenous education in Latin America is closely linked to the participation and intervention of various agencies in different countries. Such interventions have included different levels of operation, from technical to financial, such as the case of Puno German Technical Cooperation (GTZ), intervened through the Experimental Project of Bilingual EducationPuno (Lopez, 2009). The EIB is, in general, an education rooted in the culture of reference of the students, but open to the incorporation of elements and contents from other cultural horizons, including universal culture (Zúñiga, 1990), but it had and contains a diversity of problems, from the absence of clear language policies from the State, to the lack of understanding from some sectors about the importance of IBE. In short, our theoretical reference, links from the perspective of transduction, that is, from the critical perspective, in order to identify gestures, actions, experiences and practice of struggle that have been undertaken by the Aymara communities, for this we trace the presence of the school in the various Aymara provinces of the Puno region, which allowed us to delve more deeply into this task of making visible the emancipatory struggles of dignity.

We can start highlighting a very interesting work internationally, is the work of Perez (1992) under the title:
"Warisata. The school-Ayllu, where he recounts the struggle undertaken in Upper Peru (Bolivia), in the same way the work: "Indigenous education indigenous surveys (Callisaya, 2016), which recounts experience of struggle undertaken by three leaders of Camacho Province Ambana Between the years 1917-1933, the Aymara communities on the Peruvian side faced the same situations.

On the forms of discrimination we have the work of Fausto Reinaga (2010), which analyzes and puts into debate in the context of the struggle for education, On the other hand, it is important the work of Guillermo Bonfil (2001), addresses the problem mexicana, concludes that there are pending and current problems to be solved, which must be faced by the actors themselves, in our case by the communities themselves. It is important to highlight the text: "Indigenous movement in Latin America: resistance and social transformation (Escárzaga et al 2014), describes the current indigenous movement and emphasizes in the struggles of the peoples in the countries of Latin America. Emphasizes community forms and the collective sense of struggles that are being reproduced today and as responses to struggles, from the State are the criminalization of struggles, which are necessary to visualize and face. Therefore, this complication of various reflections becomes a reference and mandatory reading (Escárzaga, 2014), on the other hand, there are studies and works that relate experiences of rural education (Corvalán, 2006) (Baronet, 2015) (Bonal, 2009) (Callisaya, 2016), these authors go through the perspective of the demand for an education with a sense of pertinence and development with identity.

The process of struggle and resistance of indigenous peoples has been of interest to various studies, who decipher the history and struggle of the people, "when only the Indians reign" (Thomson, 2007), recounts the process and proposes some paths to follow, therefore, is another of the mandatory readings that shows us to track with greater and better detail. In the context of the struggle for education, it is important that Rolando Pilco study, which traces the validity and permanence of the demand for higher education in his thesis (Mallea, 2016) concludes that it is a demand to be resolved. It is a very interesting work that goes through the framework of critical reflection. On the other hand, in the national context the text: "History of education in Puno" (Portugal, 2013), is a transcendental work to understand the struggle for education of the Quechua and Aymara peoples in Puno, without detracting from other works related to the subject to work, there was disinterest to identify the struggles undertaken as the case of Manuel Z. Camacho, which still is difficult to understand and is a subject to be developed. In this trajinar we find an interesting work that 
seems to complete studies of that period "Conflict internal school and teacher in the Puneño highlands (1980-1990)" (Velasquéz, 2011), which is a working document that the same author indicates in the first part.

It is essential to highlight the contextualization of various scholars on Puno and the Altiplano, "Changes in Puno" (Bourricaud, 1967), where marked social structures are reproduced where racism and discrimination still prevailed; another of the events that has marked and stained the country with blood, although it did not have much implication in the Aymara area is political violence, therefore: "Batalla por Puno" (Renique, 2004), is necessary to have and preserve the memory so that history can never be repeated under pretexts and speeches of justification of violence, where the most affected are the Quechua, Amazonian and Aymara populations. There are other works related to the Aymaras, such as the case of Domingo Llanque, where he insists and makes visible the validity of the Aymara culture, but from his experience as a priest of the Catholic religion (Llanque, 1990), his conviction with culture and language has been truncated with his death, but has left pending tasks and subjects that are demands that are assumed by the Aymara communities, we know that he worked for several years in Ilave as parish priest.

In relation to studies related to the Aymara area, specifically Ilave, there are several studies, the interest starts from the year 2004 with the events of April 26, in that sense we have the text of "No law for us" addresses the "conflict" from the struggle undertaken by local organizations such as the case of lieutenant governors, mayors of populated centers (Pajuelo, 2015), the author describes the conflict in detail, although it does not specifically touch on the educational issue, but the problem of access and disregard for services. The text "Die in Ilave. Acronym of a conflict of the Aymara Nation with the nation-state "(Ayala, 2005), where the author tells the facts by going to the acronym; that is, to the validity of the chronicle and literary fiction. In this way we can make visible various works linked to the Aymara context that help us to define and respond to the purposes of the research. On the other hand, there are unresolved problems that have to be worked on by the fight actors themselves who claim culture and language, these proposals are proposed by these authors, to whom there is due attention.

In addition, it is corroborated that the different current communities were irrigated with haciendas, where the bosses, called by the 'ñitu' or 'misti' settlers, subjected the 'Indians' or 'jaqis' to forced and free labor. The province of Huancané and the province of Chucuito were two provinces, where the colonial backwardness was concentrated. Then with the creation of the provinces of
Yunguyo, El Collao and Moho, it will affect the local and racist elites that occupied the different positions of public and political administration, to which the Aymaras were vetoed. Therefore, access to education was essential. Major schools were created such as the National College of Boys under law No. 12859 of November 25, 1957, on the other hand it is important to highlight the founding of the first rural school in Aña Aña Huancho, by the teacher Mariano Luque Corimayhua, in the same way they were created various clandestine schools in different communities. One of the most important struggles is the Foundation of the City of Snows of Huancho Lima in an unprecedented event on August 3, 1923, as the new capital of the Tawantinsuyana Republic, in response to the atrocities committed by the gamonales. In response from the State, Rita Puma was cruelly tortured to death. Mariano Luque Corimayhua on the night of January 10, 1924, was taken from Huancané pris on and taken to Kuka Uta, where he was shot and anchored to the Huancané river, Mariano Pacco Mamani, he threw himself into the river before being shot dead. He was elected as Carlos Condorena Yujra (Ayala, 2006).

In Platería, before it was part of the province of Chucuito, Manuel Zuñiga Camacho founded the first Indigenous Rural School in the Puneño highlands in 1902 (Ruelas, 2016), where he taught reading and writing of Castilian and the study of Bible. Then it will suffer an atrocious repercussion from the State and the Catholic Church.

\section{THE CONQUEST OF THE SCHOOL BY THE AYMARA COMMUNITIES AND THE SENSE OF PERTINENCE}

The communities assumed that education as a space and stage for transformation and liberation, therefore imitated some experiences of other communities in Latin America, for that reason they chose to create and manage the school, first nominating commissions called "school patrons" who fulfilled the role of managers, today is known as the "Association of Parents" which is essentially conceived as an organization whose children study in an educational center, however, in the community they are not always the one who has a child or daughter at school, but it is a responsibility of service of the members of the community with the school, that is, there is an integral and collective concept from the community with the school and the school should correspond to the community.

State-School-Community Relationship

There are three fundamental actors of education, school, state and community, which historically legitimizes the disagreement between these actors. The state institutions from the creation of the School Nuclei to the Ugels, are state institutions that operate in the educational subject in 
the communities. There are historically unresolved problems for more than 500 years, and 200 years after the independence of Peru, it is undeniable that indigenous peoples have been and continue to be victims of subjugation, domination and exploitation (Charters \& Stavenhagen, 2010), in that line There are systems of organization and leadership that have been recreated from the Aymara communities that have been accompanying the struggle for education.

From the interviews and testimonies, it was possible to collect various information about the lieutenant governors, leaders and elders, who have provided free services to their communities, for example the lieutenant governors, met the moral and ethical requirements to fulfill this service to the community. . Throughout the management of the school they accompanied the school patrons of the community, the communal work to build classrooms, donation of land where the school was built, the lieutenant governor has always played a fundamental role.

The communities were able to recreate their forms of organization against other systems and structures imposed by development agents. School patronages today are called from the standards of the Ministry of Education, as Association of Parents of Family (APAFA), for the fundamental right, is a stable organization of natural persons, nonprofit, legal personality of private law and can register in the Public Registries. It is regulated by the Civil Code, in what is pertinent, the General Law of Education, the APAFA institutionally channels the right of parents to participate in the educational process of their children (Education, 2017).

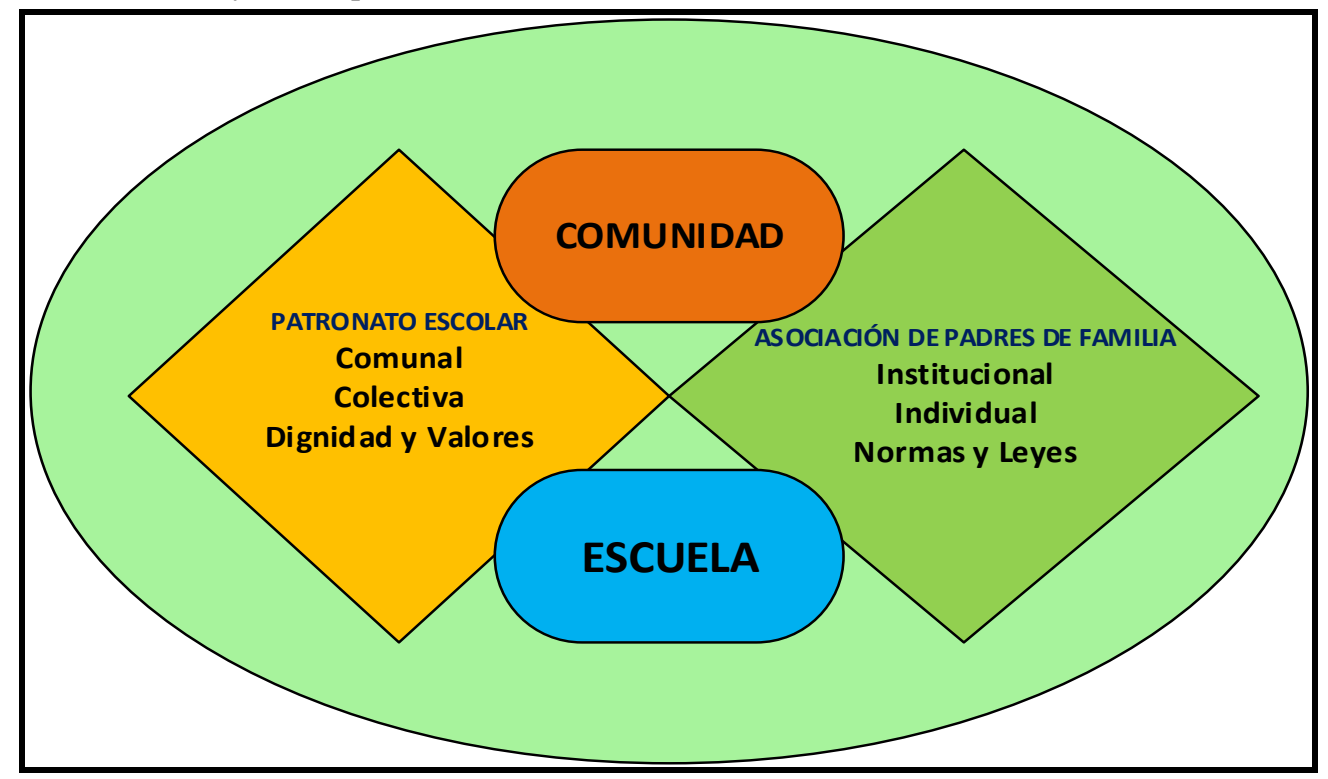

Fig.1: School Board-Parent Association

From Figure 1, we can decipher that the school board is a communal expression, that is, it is constituted and formed under a collective perspective and points to a practice of daily life, which entails and induces respect and dignity within the framework of Aymara cultural values and its visibility is more complex. On the other hand, the association of parents, is instituted under institutional canons, transits through the individualist line anchored and reinforced by rules and laws. But it was not always relevant or contextual.

It is relevant that they can draw continuities between their personal context and ethnic identity and the task they have assumed as active promoters of community education (Kreisel, 2016), although not all, but the vast majority of teachers were inserted in a relevant and appropriate manner. to the community and the community he was fond of his teachers. From their experience the population of the communities did not presage, the supreme aim of the peasant school is to make the Indian child a Europeanized child. A cholo K'ara. Putting in the Indian child, instead of his brain another brain, means, making his person another person (Reinaga, 2010). In this scenario, two important aspects are visualized, a first one referred to the process of vindication, which will be translated into the demand of "reading and writing" and the meaning that language has in the process of struggle for dignity. On the other hand, it has other connotations such as racism, exclusion, discrimination and environmental, still in force in the community.

The Aymara language is the most predominant language in the population of the communities, this situation in recent years has undergone considerable changes and transformations due to the contempt and rejection by social issues of the parents, therefore, each time less is spoken the Aymara language For this it is necessary to 
know the population of the Aymara communities of the Puno region.

\section{CHALLENGES AND HOPES OF EDUCATION FOR THE AYMARA COMMUNITIES}

Education for the Aymara communities is an instrument of emancipation, from the Aymara language it is translated as: "yatiqaña" "knowing" 'knowing' 'praxis', in short it becomes the wisdom rooted in experience and practice. However, the school, the college and the university have recreated from their practical responses to each aspect, legitimizing racism, exclusion, discrimination and extractivism. Therefore, the political, socio-cultural, economic and environmental spaces are scenes of struggle for the Aymara populations.

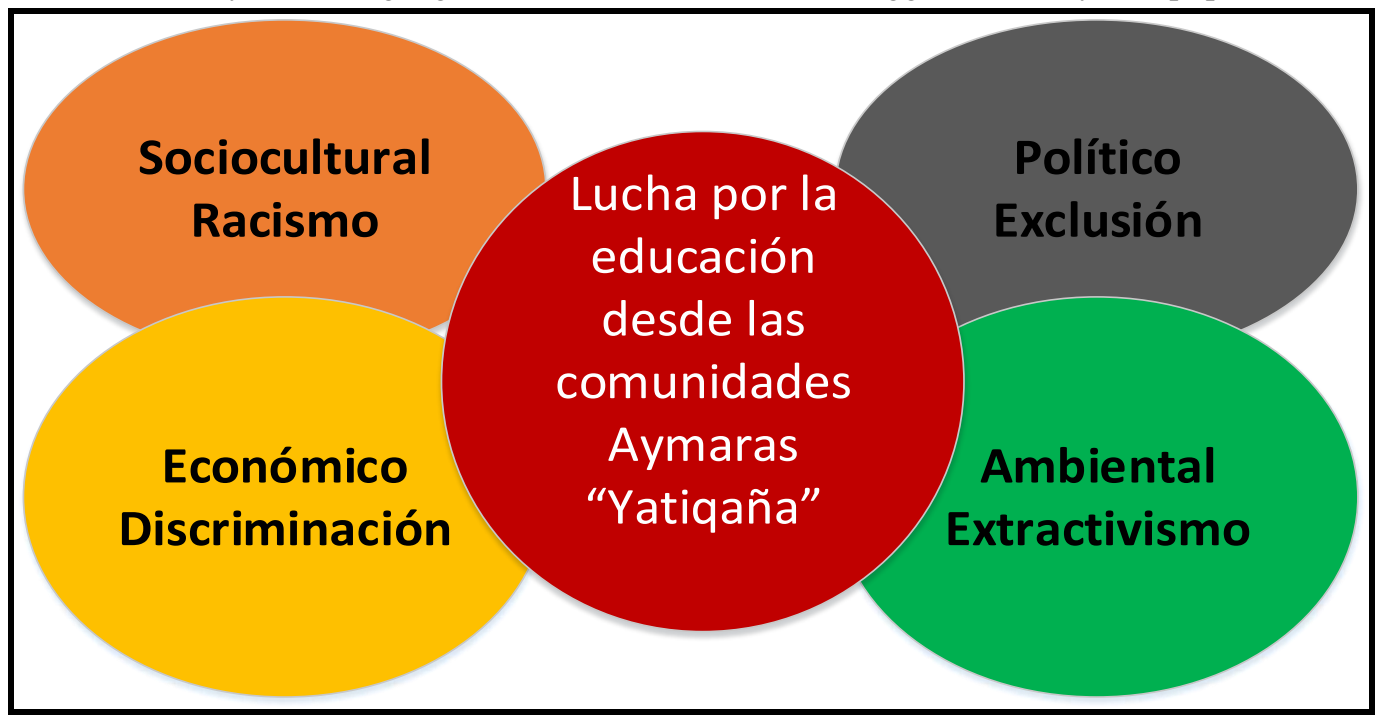

Fig.2: Connotative aspects of the educational claim in the communities (2017).

Figure 2 illustrates the four main aspects that could be solved through the conquest of a School in the community, with a sense of pertinence.

One of the aspects that had to be resolved or confronted with the school was the racism that had been culturally and socially constructed, because even the colonial past leaps and revives in abuse and abuse where a society confronts us daily with injustice and injustice and violence. I presume that the reasons for this situation are evident: ethnic domination, racism, generates a conflict, sometimes latent and dissimulated, at other times, open and bloodthirsty (Portocarrero, 2009), because the reciprocal feeling between and of the different strata is still far away social that have been built on that colonial base that is increasingly reproduced as a kind of resentment and hatred. On the other hand, the mobilizations against invisibility and racism took place in a global context in which the social changes that took place between the 1950 s and the 1970 s led to the emergence of new social actors with claims for civil rights and the cultural affirmation, "novel" aspects in the scenario of the political and intellectual debates of the country (Castillo \& Caicedo, 2015), in the same way it will take place in the region, especially assumed by the communities. However, little progress has been made.

The political practices linked to the question of representative democracy that the country has lived since
1980 established under "democratic governments" today seem to be more evidence of corruption and the social and environmental collapse we are witnessing is becoming more evident. it requires us to look at spaces or scenarios of hope, as are the ancestral communities that have not yet been contaminated by their organizational, collectivist, ecological systems and above all with the supremacy of dignity, over norms.

A portas to celebrate the 200th anniversary of the independence of Peru, the population of the ancestral peoples such as the Quechua, Amazonian and Aymara, are not actors or participants in the decision spaces at the level of the central government, in fact, local governments and regional where they participate, does not have much significance in the education of the people. But, if they remember at electoral moments, and history has shown us that, the Indian vote in the hands of the white-mestizo cholaje, is an instrument of oppression of the Indian. Thanks to his own vote, the Indian has become "politician". The political "ponguaje" of the Indian is the support of the political parties: the "political-military" party of the Armed Forces, of the mestizo nationalism (Reinaga, 2010).

Although it may sound illogical, there are certain historical vagaries about the conception of education in this context of globalization, education, of course, not only has not been an exception but a privileged space of 
production of the hegemonic discourse. There are two fundamental reasons to explain it. On the one hand, education is a fundamental component for the construction of so-called "knowledge societies", and it is these social formations that can obtain the greatest comparative advantage in the face of economic globalization (Bonal, 2009).

The peasant-indigenous communities in Peru, as in the rest of the Andes, are political instances, forms of authority whose presence goes beyond the limits of the State. They maintain forms of sovereignty distinct from state sovereignty (Pajuelo, 2016). The commitment to the demand for education in the communities has responded to a "Western" school model because it was tailored to the "official school" although some expectations have been resolved, but in the process it was dissociated from the community. The reaffirmation of ethnic identity in school practice is related to the ethnopolitical positions that sustain the project and are reflected in the discursivity of its actors; touches, at a broader level, the collective right to self-determination of indigenous peoples (Kreisel, 2016).

On the other hand, the Aymara communities, generally, according to their traditional system were organized as follows:

- Jilaqata, was the maximum representative, is currently represented by the lieutenant governor

- P'iqiña, was responsible for or responsible for the control system of the livestock and agricultural activities of the community, today some call field or Remato, here has been anchored a structure of the colonial system. It's exactly like the Ronderos at the communal level.

- Jilparinaka, are elderly or experienced at the community level and become consultants and teachers of the community administration.
- Sullkirinaka, are the minor adults, who participate in the communal activities.

- Achunaka, are members of extended families that are linked to the community from a relationship of kinship.

The destructuring of the communities is evident because it is growing in an unplanned way, without technical orientation, or an empirical question of modern development, the dominant thought is, until now to feel the territory as a homeland (Bilbeny, 2007), it is necessary the effort they carry out the communities to survive. But little is done by local governments, the regional government and the State itself by the peasant communities and by education with a sense of pertinence. Educational systems often reinforce the differences between groups that supposedly have the same opportunities to learn, but that are related to these opportunities in a very different way (Balarin, 2008). In that sense, a dialogue, based on sincere interest in the other, on the commitment and the certainty that each one can be enriched by the experiences of others, is essential for the success of an integration project. It should be composed of authentic words that allow an interplay between action and reflection and result in praxis (Crestanello, 1998).

Now, the role of the school in the communities was decisive in its first stages, we will say, from the creation, but, as time went by, it lost the protagonism at the communal level, and vice versa, that is, that the community has been gradually disconnected, obviously there is no complete rupture, but it becomes fragile and becomes a distrust and a threat to the community, so we can represent in the following figure:

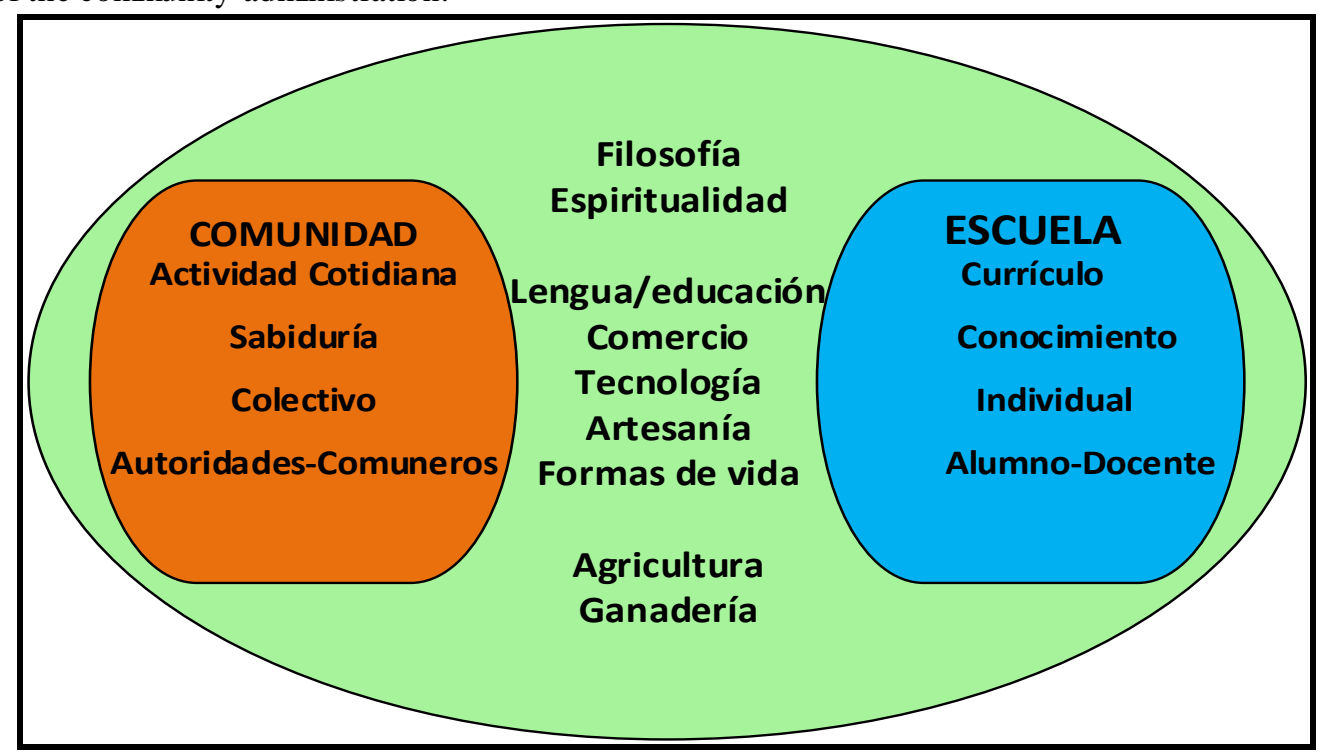

Fig.3: Role of the school in the community (interviews: 2017). 
From the figure it follows that the community focuses on daily activity, while the school in the curriculum; the community in wisdom and the school in positivized knowledge; the school focuses more on the collective level, the community on the collective level; the actors of the school are the students and the teacher; while in the community they are authorities and comuneros. They link certain elements such as agriculture and livestock, ways of life, philosophy and spirituality that remain in force in communities, trade, technology and crafts, all these aspects can be linked from the language that is still a element of transformation for communities.

The Aymara phrases define the sense of identity from the communities and the following phrases could be identified:

"Nanakaxa aymarapxtwa" 'we are Aymara'

"Jiwasanakaxa aymaranakpxtwa" 'we are Aymara'

"Aymarata parlasiripxtwa" 'we are Aymara speakers'

The residents of the community have been disconnected, and several sayings could be identified from our informants, such as:

"Uywampi yapumpi jakasiritanwa" 'we live with the farm and livestock'

"Yatiñawa uywa uywachaña" 'You have to know how to raise animals'

"Uywaxa tukusiriwa" 'animals can become extinct'

These phrases are closely linked to the wisdom of upbringing and living, that the formal education represented by the school, the college and the university, that have legitimized the systematic extinction of the alpaca and the llama, that no longer breed, that is to say, has disconnected from its environment.

Currently within the Peruvian university system we live the process of standardization since the change of the university law, which in short, is the homogenization of university careers, under the assumption of improving quality, it aims to eliminate those careers that for capitalism is no longer profitable. In short, it is an act of injustice. Faced with this, students have to struggle to have an education with a sense of relevance and contextualized and can help solve the critical problems facing the country, such as insecurity, discrimination, corruption and extractivism.

\section{v. CONCLUSIONS}

For the Aymara communities settled in Puno (Peru), the right to education with a sense of pertinence remains a problem to be solved. The process of struggle was a response and demand to the atrocities that have been committed in the different communities, where they had watered haciendas. Therefore, the aim of the claim was to read and write in Spanish, for this reason it has cost and costs education and pain for the inhabitants of the Aymara communities. In the conquest of the school three important actors are visualized, the trinomial: StateSchool and Community, but disconnected and disconnected among them. The process of vindication for education, remains an unresolved problem, in the aspects, political, sociocultural, economic and environmental, because the responses from the State have responded to a model of "western" school "official school", which still it does not anchor in daily practices, agriculture, livestock, in its ancestral and communal values and principles. The educational system is increasingly exclusive, as in the case of universities today, with the new university law, a hegemonic standardization process has been implemented, under the anchors of capitalism, that is, it has been dissociating itself from the community.

\section{REFERENCES}

[1] Alanoca , V. (2016). El desarrollo del pensamiento crítico en el altiplano de Puno. Comuniacción vol.7 no.2 Puno jul./dic. 2016, 7(2), 60-68. Recuperado el 10 de 09 de 2018, de http://www.scielo.org.pe/pdf/comunica/v7n2/a06v $7 \mathrm{n}$ 2.pdf

[2] Alanoca, V. (2012). El buen vivir en la cultura aymara. Saarbrücken: EAE.

[3] Alanoca, V. (2013). Conflictos aimaras. Puno: Universidad Nacional del Altiplano.

[4] Alanoca, V. (2016). Apuntes sobre el proyecto sierra sur en el Collao-Ilave. Puno: Emer impresiones.

[5] Albo, X. (1988). Raíces de América: El mundo aymara. Madrid: Unesco.

[6] Albó, X. (1992). Bases étnicas y sociales para la participación aymara en Bolivia. La fuerza histórica del campesinado. En E. Kingman, Ciudades de los andes (págs. 375-389). Quito: Ciudad.

[7] Araujo, L. (2013). Teorías contemporaneas del aprendizaje. Arequipa: Edimag.

[8] Ayala, J. (2005). Morir en Ilave. Acrónica de un conflicto de la Nación Aymara con el Estadonación. Lima: San Marcos.

[9] Ayala, J. (2006). El presidente Carlos Condorena Yujra. Lima: San Marcos.

[10] Balarin, M. (2008). La calidad de la participación de los padres de familia y el rendimiento estudiantil en las escuelas públicas peruanas. Lima: Niños del milenio.

[11] Baronet, B. (2015). El movimiento zapatista y la educación para la autonomía. En P. Medina, Pedagogías insumisas (págs. 49-71). México: Universidad de Ciencias y Artes Chiapas.

[12] Bilbeny, N. (2007). La identidad cosmopolita. Barcelona: Kairós.

[13] Bonal, J. (2009). La educación en tiempos de globalización: ¿a quien beneficia? Educação \& 
sociedade, 30(108), 653-671. Recuperado el 29 de noviembre de 2017, de http://www.scielo.br/pdf/es/v30n108/a0230108

[14] Bonfil, G. (2001). México profundo, una civilización negada. México: Conaculta.

[15] Bourricaud, F. (1967). Cambios en Puno. Lima: Instituto de Estudios Peruanos.

[16] Burga, Elena, Hidalgo, Liliam y Trapnell, Lucy. (2012). La Escuela Intercultural Bilingüe. Aportes para garantizar un servicio de EIB de calidad. Lima: Family Health International.

[17] Callisaya, P. (2016). Levantamientos indígenas educación indigenal. La Paz: Diario.

[18] Cassirer, E. (1968). Antropología filosófica. México: Fondo de Cultura Económica.

[19] Castillo, E., \& Caicedo, J. A. (2015). Las batallas contra el racismo epistémico de la escuela Colombiana. Un acontecimiento de las pedadogías insumisas. En P. Medina, Pedagogías insumisas (págs. 96-117). México: Universidad de Ciencias y Artes de Chiapas.

[20] Cerrón-Palomino, R. (12 de Febrero de 2016). Educación Intercultural Bilingüe: “iEs una farsa!” . Los Andes, pág. 8.

[21] Charters, C., \& Stavenhagen, R. (2010). El desafio de la declaración. Copenhague: Iwgia.

[22] Corvalán, J. (Julio-diciembre de 2006). Educación para la población rural en siete países de América Latina. Síntesis y análisis global de resultados por países. Revista colombiana de educación (51), 40-79. Recuperado el 30 de noviembre de 2017, de http://www.redalyc.org/pdf/4136/413635245003.pdf

[23] Crestanello, A. (1998). Preguntas para la acción. Ensayos y experiencias, 57-65.

[24] Cultura, M. d. (2014). Aimaras comunidades rurales en Puno. Lima: Ministerio de Cultura .

[25] De Puelles, M. (23 de Abril de 1993). Estado y educación en las sociedades europeas. Recuperado el 25 de agosto de 2017, de http://rieoei.org/oeivirt/rie01a02.htm: http://rieoei.org/oeivirt/rie01a02.htm

[26] Delagado, K. (2005). Educar desde la crísis. Lima: San Marcos.

[27] Díaz, L. (1959). Informe sobre los Núcleos Escolares 1946-1958. . Lima: Ministerio de Educación Pública - Servicio Cooperativo Peruano Norteamericano de Educación.

[28] Ministerio de Educación del Perú (2017). Currículo nacional de la educación básica. Lima: Ministerio de Educación.

[29] Encinas, J. A. (2007). Un ensayo de la escuela nueva en el Perú. Puno: Universidad Nacional del Altiplano.
[30] Escalante, Y. (2009). Derechos de los pueblos indígenas y discriminación étnica o racial. México: Atril excelencia editorial.

[31] Escárzaga, F. (2014). Movimiento indígena en América Latina: resistencia y transformación social. México: Ceam.

[32] Espinoza, G. A. (2010). The origins of the núcleos escolares campesinos or clustered schools for peasants in Peru, 1945-1952. Revista electrónica de la Asociación Española de Americanistas. Recuperado el 12 de noviembre de 2017, de Espinoza, G. A. (2010). The origins of the núcleos escolares campesinos or clustered schools for peasants in Peru, 1945-1952. En: Revista electrhttp://revistas.um.es/navegamer

[33] Frisancho, M. (1946). Los tiranos no nacen sino que los hacen. Buenos Aires: Instituto del Libro.

[34] García, N. (2004). Diferentes, desiguales y desconectados. Barcelona: Gedisa.

[35] García, N. (2006 [1989]). Culturas híbridas. Sao Paulo: Edusp.

[36] Hessen, J. (1947). Teoría del conocimiento. Buenos Aires: Losada.

[37] Jiménez, M. (2008). Aproximación teórica de la exclusión social: Complejidad e imprecisión del término. Consecuencias para el ámbito educatico. Estudios pedagógicos, 173-186.

[38] Justo, M. (2017). Corrucpion. Lima: Horizonte.

[39] Kreisel, M. (2016). Reivindicaciones del derecho a una educación propia: La figura del educador comunitario. $\quad$ Alteridad, doi:10.17163/alt.v1 $\ln 1.2016 .02$

[40] Laos, A. (2004). Las comunidades campesinas en el siglo XXI. Lima: Grupo Allpa.

[41] Layme, F. (2011). Mundo Aymara. En B. Ludovico, Vocabulario de la lengua aymara. La Paz: Radio San Gabriel.

[42] Llanque, D. (1990). Llanque Chana, D. (1990). La cultura aymara. desestructuración o afirmación de identidad. Lima: IDEA, Tarea. Lima: IDEA, Tarea.

[43] Lopez, E. (2009). Interculturalidad, educación y ciudadanía. La Paz: Plural.

[44] Luengo, J. (2004). La educación como objeto de conocimiento. En M. e. Mar del Pozo, Teorías e instituciones contemporáneas de educación. (págs. 30-47). Madrid: Biblioteca Nueva.

[45] Maletta, H. (2015). Hacer ciencia. Lima: Universidad del Pacífico.

[46] Mallea, P. (2016). Construcción colectiva de las demandas y propuestas de educación superior indígena en el Perú: el caso de la Unión Nacional de Comunidades Aymaras-Unca (1980-2014). Cochabamba: Universidad Mayor de San Simón. 
[47] Malmberg, B. (1966). La lengua y el hombre. Madrid: Istmo.

[48] Mariategui, J. C. (2002). 7 ensayos de interpretación de la realidad peruana. Lima: Ediciones cultura peruana.

[49] Matos, J. (1976). Hacienda comunidad y campesinado en el Perú. Lima: Instituto de Estudios Peruanos.

[50] Matos, J. (1984). Desborde popular y crisis del Estado. Lima : Instituto de Estudios Peruanos.

[51] Pajuelo, R. (2015). No hay ley para nosotros. Puno: Universidad Nacional del Altiplano.

[52] Pajuelo, R. (2016). Río invisible. Lima: Ríos profundos.

[53] Palomino, C. (1980). Instituto de Lingüístico de Verano un fraude. Lima: Rupa Rupa.

[54] Pérez, E. (1992). Warisata. La escuela-ayllu. La Paz: Hisbol.

[55] Portocarrero, G. (2009). Racismo y mestizaje y otros ensayos. Lima: Fondo Editorial de Congreso del Perú.

[56] Portugal, J. (2013). Historia de la educación en Puno. Puno: Universidad Nacional del Altiplano. p. 442. Puno: Universidad Nacional del Altiplano.

[57] Reinaga, F. (2010). La revolución india. La Paz: Wagui.

[58] Renique, L. (2004). Batalla por Puno. Lima: Instituto de Estudios Peruanos.

[59] Reyes, M. (05 de 06 de 2012). ¿En qué consiste el proceso eduactivo? Obtenido de https://es.scribd.com/user/154680504/FernandaEsperanza-Ayala-Catalan: https://es.scribd.com/doc/97230741/En-queconsiste-el-proceso-educativo

[60] Rodríguez, G., Gil, J., \& García, E. (1996). Metodología de la investigación cualitativa. Granada: Aljibe.

[61] Ruelas, D. (2016). La escuela rural de Utawilaya. Una educación liberadora desde Puno-Perú 1902. Historia de educación Latinoamericana, 243-262.

[62] Santos de Sousa, B. (2017). Justicia entre saberes: Epistemilogias de Sur contra epistimicidio. Madrid: Morata.

[63] Sartori, G. (1998). Homo videns . Buenos Aires: Taurus.
[64] Sarzuri, M. (2014). La lucha por «comunitarizar» la educación. Construcciones desde el subsuelo político. Foro de Educación, 169-190.

[65] Sosa, P. (2017). Docencia. Puno: Altiplano.

[66] Tapia, A. (Octubre de 1964). Educación fundamental. Unanchiri, 7-8.

[67] Taylor, J., \& Bogdan, R. (1984). Introducción a los métodos cualitativos de investigación. Barcelona: Paidos.

[68] Thomson, S. (2007). Cuando sólo reinasen los indios. La Paz: Muela del diablo.

[69] Tuoraine, A. (2006). Los movimientos sociales. Revista colombina de sociología, 255-278.

[70] Valcarcel, L. (1973). Ruta cultural del Perú. Lima: Universo.

[71] Vargas, P. (1983). Movimiento campesino peruano (1945-1964) : algunos elementos de analisis preliminares y una aproximacion bibliografica. Lima: Centro Peruano de Estudios Sociales.

[72] Velasco, H. (2013). Hablar y pensar, tareas culturales. Madrid: Universidad Nacional de Educación a Distancia.

[73] Velasquéz, L. (2011). Conflicto interno escuela y maestroen el altiplano puneño(1980-1990). Puno: Qhala editores.

[74] Vygotsky, L. S. (1995). Pensamiento y lenguaje. Buenos Aires: Fausto.

[75] Webb, R. (2013). Conexión y despegue rural. Lima: Universidad San Martin de Porres.

[76] Weingberg, G. (1984). Modelos educativos en la historia de América Laina. Buenos Aires: Kapeluz.

[77] Wolkmer, A. C. (2006). Pluralismo jurídico. Sevilla: Mad.

[78] Zaldívar, P. (2011). Hacia un nuevo paradigma transformación educativo. Lima: San Marcos.

[79] Zorrilla, M. (13 de junio de 2002). ¿Que relación tiene el maestro con la calidad y la equidad en educación? Recuperado el 15 de setiembre de 2017, de

www.oei.es/historico/.../relacion_maestro_calidad_e quidad_educacion_zorrilla.pdf:

www.oei.es/historico/.../relacion_maestro_calidad_e quidad_educacion_zorrilla.pdf

[80]Zúñiga, M. (1990). Educación bilingüe intercultural: reflexiones $y$ desafios. Lima: Fomciencias. 